\title{
SCIENTOMETRICS-BASED STUDY OF COMPUTER SCIENCE AND INFORMATION SYSTEMS RESEARCH COMMUNITY MACRO LEVEL PROFILES
}

\author{
Erman Coşkun ${ }^{1}$, Güzin Özdağoğlu², Muhammet Damar ${ }^{2}$ and Büşra Alma Çallı ${ }^{3}$ \\ ${ }^{1}$ Prince Mohammad Bin Salman College (MBSC) of Business \& Entrepreneurship, Saudi Arabia \\ ${ }^{2}$ Dokuz Eylül University, Turkey \\ ${ }^{3}$ Sakarya University, Turkey
}

\begin{abstract}
This paper examines the current state and evolution of Computer Science (CS) and Information Systems (IS) research communities for the period of 2008 to 2019 by analysing Web of Science (WoS) core collection records. In order to compare and examine research outputs, the study period was divided into two time-periods. The first period included articles published between 2008 and 2013 and the second period included articles published between 2014 and 2019. Several analyses are presented in the scope of scientometrics regarding the (a) countries (b) historical occurrence-time (c) institutions (d) author collaboration (e) study topics-keywords (f) journals. This paper provides meta-analysis in different areas. We believe that our analysis results will shed a light for each area as well as interaction and intersection between both areas. As IS discipline and researchers we need to understand these intersections and interactions as well as understanding current trends in both disciplines.
\end{abstract}

\section{KEYWORDS}

Computer Science, Information Systems, WoS Publications, Macro Level Profiles, Scientometrics

\section{INTRODUCTION AND BACKGROUND}

Number of IS research and utilization of IS as reference discipline has been rising The Information Systems (IS) community has been developed significantly after its first emergence in the 1960s. A robust research tradition has been established and has guided IS to be grown into a scientific field. IS, as a reference discipline, is within the focus of researchers from other disciplines as well, which contributes to knowledge accumulation and growth of the field (Paré et al. 2014). Computer science is one of the major disciplines interacts and intersects with IS. Information Systems (IS), referring to Management Information Systems (MIS) and Computer Information Systems (CIS), integrates social and technical approaches with an interdisciplinary view. IS field has researchers from different backgrounds and disciplines (Alma et al., 2017). Terms of MIS, IS and CIS are often utilized interchangeably and different researchers have conceptualized the field in a different way.

Examining the state-of-the-art and evolution of academic discipline has been a traditional approach for observing the changes and developments within the field. Compared to other disciplines, IS is a new and fast developing discipline. Undoubtedly, examining the development of an academic field contributes the ongoing development of the discipline as it offers the opportunity of comparing past and present status of the research output, exploring research gaps, capturing trends and topics that have not been addressed and observing methodological issues (Serenko et al., 2008). Hence, some IS research have concentrated on theoretical overviews of the field and have examined theoretical IS research from numerous aspects (Abbasi et al. 2016; Banker \& Kauffman, 2004; Cheon et al., 1993; Choi et al., 2011; Dickson, 1981; Palvia et al., 2003; Paré et al., 2014; Serenko et al., 2008; Shao et al., 2014).

This study, conducts several analyses in the scope of scientometrics for a sophisticated review of research and publication characteristics of IS research by encompassing a long-period of publication. Depending on the limited amount of research and aforementioned shortcomings of the previous review studies, this study contributes to evaluating the maturity of the field, trends and research gaps. To do so, a large-scale data set is 
analysed covering the research articles which were published between 2008 and 2019 and categorized under "Computer Science-Information Systems" within Web of Science(WoS) Core Collection. Studies in the scope of scientometrics facilitate this by exploring past and present status of the field by enabling analysing a wide range of publication characteristics in addition to subject trends. Furthermore, a huge amount of publication data extracted and gathered systematically facilitates conducting comprehensive analysis from a wide range of aspects. In order to compare the recent trends to the previous ones, the study period was divided into two time-periods. The first period included articles published between 2008 and 2013 and the second period included articles published between 2014 and 2019. Several analyses are presented in the scope of scientometrics regarding the countries, institutions, author collaborations, journals, and topics-keywords.

\section{SHORT LITERATURE REVIEW}

One of the earliest studies evaluating research in IS was performed by (Cheon et al., 1993) by synthesizing the associated research in order to evaluate the maturity of the field. Banker and Kauffman (2004) evaluated the IS literature within Management Science discipline for the last five decades by discussing major research streams within the field. Those research streams were identified as follows; "decision support and decision science", "the value of information, human-computer systems design", "IS organization" and "strategy and economics of IS and technology". Shao et al. (2014) conducted an overview of MIS literature with the aim of comparing domestic research in China with foreign research trends. In addition to research subjects, methodologies, journals and research output of MIS researchers were analysed and discussed. Abbasi et al. (2016) specifically focused on Big Data research in IS with concentrating on subjects and research gaps within the field. Choi et al. (2011) worked on the identification of the keyword patterns by analyzing MIS research publication data between 1999 and 2008. Rapid changing nature of the field was observed by means of network perspective. Interdisciplinary nature of the field was reflected by various concepts and areas emerged from a substantial combination of existing topics and concepts. Palvia et al. (2003) systematically reviewed top MIS journals covering a five-year publication period to analyse trends for subjects and methodologies. Paré et al. (2014) specifically reviewed the various review types published in top IS journals. Freitas et al. (2004) compared research characteristics in MIS for France and Brazil by focusing on particular domestic congresses. Evolution of subject in the 4-year period, number of citations and characteristics of congresses. Vessey et al. (2002) synthesized IS research papers published between 1995 and 1999 in five IS journals. Topics, research methodologies, and their evolution was analysed.

Most papers of the relevant literature conducted overview studies with mostly focusing on research trends and methodologies within IS / MIS research. A common aspect of papers was to cover a relatively short analysis period that constitutes limitations in anticipating actual trends, methodologies and research activities.

\section{METHODOLOGY}

\subsection{Research Scope}

This study mainly focuses on the area "Computer Science-Information Systems" to reveal information on following areas:

- Publication statistics,

- Country related statistics and collaboration analysis,

- Institution related analysis,

- Research topic and area related analysis,

- Keywords and relevant topic analysis

By doing so, the study aims to present the leading countries, authors and research fields in the relevant literature with summary statistics, and to present the collaborations between the countries, the issues and their changes over time with advanced analyses based on scientometrics and visuals. 


\subsection{Data Source and Data Characteristics}

The analyses were carried out through publications within the WoS database which has an important position in the international literature. Every publication covered by WoS Core Collection is assigned to at least one of 254 subject categories. There are seven categories, especially those relating to computer science and information systems, i.e. Computer Science, Artificial Intelligence (1); Computer Science, Cybernetics (2); Computer Science, Hardware \& Architecture (3); Computer Science, Information Systems (4); Computer Science, Interdisciplinary Applications (5), Computer Science, Software Engineering (6); Computer Science, and Theory \& Methods (7), respectively. The bibliometric dataset of original articles, which was tagged under these seven research categories, is included in the analyses.

The article search and data set extraction were conducted in 24.02.2019, and all original articles published from January 2008 to February 2019 were taken into consideration in the scope of the study. The main reason behind selecting only the original articles is the thought that the articles can be representative to reveal the major research patterns in the literature. During the analyses, the raw dataset was divided into two periods, 2008-2013 and 2014-2019, to be able to compare the trends and the characteristics in the related part of the literature. The first period consists of 57347 articles where the second period consists of 96219 articles.

\subsection{Scientometrics and Related Techniques}

The datasets were analysed through the techniques in the scope of scientometrics. Scientometrics is a concept in metrology as is the case in bibliometrics, informetrics or similar terms, which defines an old methodology, has been developed since 1960s, to reveal the characteristics of the particular literature over bibliometric datasets by using quantitative techniques (Glänzel \& Schoepflin, 1994; Hood \& Wilson, 2001; Garfield, 2009; Siluo\& Qingli, 2017). In addition to the particular metrics and summary tables, the methodology utilizes advanced text and network analytics to extract clusters and networks for citations, co-citations, co-authorships, and co-occurrence networks through various attributes such as authors, countries, institutions, and journals (Sengupta 1992; Al 2008). All these analyses and networks shed light on the demographics, collaborations, and associations in the related literature, thus the visualizations reflect the academic social network of the related area over the selected publications as well as the publication performances and summary statistics. For example, in this study, the co-authorship analysis provided a vision of cooperation patterns between individuals and organizations and sometimes countries. Time dimension was added to see the change these collaborations over the years. Besides, keyword co-occurrences were extracted the keyword trends, associations, and densities over text clustering. The widespread use of scientometrics and its development have increased along with the developments in data science and software technologies. In this study, spreadsheets and VOSViewer application software (van Eck \& Waltman, 2013) were used to obtain summary tables, to perform text analytics and to visualize the corresponding networks.

\section{FINDINGS AND DISCUSSION}

\subsection{Publication Distributions over Years}

The general status of all publications and the position of the articles in the publications are shown in Table 1 . The number of publications in all types has increased during the second period. When we check yearly publication numbers from 2008-2019, we see a steady increase every year. However, after detailed analysis of two periods, we do not see the same steady increase in conference proceedings. The economic difficulties and crisis in the university system and in-country economies might be contributing to this by reducing participation in international conferences because of budgetary limitations. Or other reason might be an increasing number of journals in the area. Nevertheless, further in-depth research must be conducted to make certain judgment however the trend shows that along conference participations are staying at the same level while the number of journal publications is increasing. 
Table 1. Document Types and Counts

\begin{tabular}{|l|r|r|r|r|}
\hline \multirow{2}{*}{ Document Type } & \multicolumn{2}{|c|}{$\mathbf{2 0 0 8 - 2 0 1 3}\left(\mathbf{1}^{\text {st }}\right.$ Period) } & \multicolumn{2}{c|}{$\mathbf{2 0 1 4 - 2 0 1 9}\left(\mathbf{2}^{\text {nd }}\right.$ Period $)$} \\
\cline { 2 - 5 } & No. of Publications & $\mathbf{2 2 0 5 2 9} \%$ & No. of Publications & $\mathbf{2 5 2 0 1 0 \%}$ \\
\hline Proceedings Paper & 160092 & 72.59 & 150585 & 59.75 \\
\hline Article & 57347 & 26.00 & 96219 & 38.18 \\
\hline Editorial Material & 3512 & 1.59 & 4111 & 1.63 \\
\hline Review & 724 & 0.32 & 1687 & 0.66 \\
\hline Book Review & 683 & 0.31 & 255 & 0.10 \\
\hline Correction & 216 & 0.09 & 355 & 0.14 \\
\hline Others & 267 & 0.21 & 539 & \multicolumn{2}{c}{0.21} \\
\hline
\end{tabular}

In terms of language, approximately 98\% of papers in both periods were written in English. Portuguese and Spanish are the most commonly used languages after English.

\subsection{Country and Institution Related Analysis}

In the light of the findings presented in Table 2 and Table 3, it can be revealed that the US and US university leadership in the first period has not continued in the second period and China and Chinese institutions were recently dominating the area based on the data we used. Our institution wise analysis, reveal that two Chinese institutions are leading in terms of publications in the area and only 1 US institution is staying in the top 10 list (comparing to 5 in the previous period). One important point is to recognize that Chinese universities outperformed others with significant increases. In terms of countries, not only China's outstanding performance but also developing countries such as India and Brazil is also getting attention by entering the list in the latest. Table 4 also presents the top institutions in each country contributing the field with the highest number of articles in addition to the most collaborative countries. We can conclude that China is a shining star for the second part and significantly dominating the discipline in terms of publications, and a number of institutions. Another important topic is collaboration and similar conclusions can be made however because of space limitations we will keep it for our presentation.

Table 2. Institutions

\begin{tabular}{|c|c|c|c|c|c|c|}
\hline \multirow[t]{2}{*}{ \# } & \multicolumn{3}{|l|}{$2008-2013\left(1^{\text {st }}\right.$ Period $)$} & \multicolumn{3}{|l|}{ 2014-2019 (2 ${ }^{\text {nd }}$ Period $)$} \\
\hline & Affiliations & $\mathbf{N}$ & $\%$ & Affiliations & $\mathbf{N}$ & $\%$ \\
\hline 1 & University of California System (US) & 1447 & 2.52 & Chinese Academy of Sciences (CHINA) & 3308 & 3.43 \\
\hline 2 & Chinese Academy of Sciences (CHINA) & 1264 & 2.20 & $\begin{array}{l}\text { Beijing University of Posts } \\
\text { Telecommunications (CHINA) }\end{array}$ & 1459 & 1.51 \\
\hline 3 & Tsinghua University (CHINA) & 778 & 1.35 & Tsinghua University (CHINA) & 1430 & 1.48 \\
\hline 4 & International Business Machines IBM (US) & 736 & 1.28 & University of California System (US) & 1416 & 1.47 \\
\hline 5 & University of Texas System (US) & 702 & 1.22 & Xidian University (CHINA) & 1256 & 1.30 \\
\hline 6 & $\begin{array}{l}\text { Centre National De La Recherche Scientifique } \\
\text { CNRS (FRANCE) }\end{array}$ & 695 & 1.21 & $\begin{array}{l}\text { Centre National De La Recherche } \\
\text { Scientifique CNRS (FRANCE) }\end{array}$ & 1081 & 1.12 \\
\hline 7 & State University System of Florida (US) & 638 & 1.11 & $\begin{array}{l}\text { University of Electronic Science } \\
\text { Technology of China (CHINA) }\end{array}$ & 1034 & 1.07 \\
\hline 8 & Nanyang Technological University (CHINA) & 587 & 1.02 & Shanghai Jiao Tong University (CHINA) & 995 & 1.03 \\
\hline 9 & $\begin{array}{l}\text { Nanyang Technological University National } \\
\text { Institute of Education Nie Singapore (CHINA) }\end{array}$ & 587 & 1.02 & Zhejiang University (CHINA) & 982 & 1.02 \\
\hline 10 & University System of Georgia (US) & 563 & 0.98 & $\begin{array}{l}\text { Indian Institute of Technology System } \\
\text { IIT System (INDIA) }\end{array}$ & 941 & 0.97 \\
\hline
\end{tabular}

In the first period, 14425 universities contributed to 57347 articles whereas in the second period 25029 universities contributed to produce 96219 articles. In both periods, the number of researchers having at least 20 articles are 960 and 1613 where the numbers of countries having at least 50 articles are 442 and 771 respectively. The institutions in China, US, and France have dominated the field in terms of their paper counts, however, in the second period India takes place as a new country with the papers produced by the Indian Institute of Technology System. 
Table 3. The Top 10 Countries in the Related Area

\begin{tabular}{|c|c|c|c|c|c|c|c|c|}
\hline \multirow[t]{2}{*}{$\#$} & \multicolumn{4}{|c|}{$2008-2013\left(1^{\text {st }}\right.$ Period $)$} & \multicolumn{4}{|c|}{ 2014-2019 ( $\left(2^{\text {nd }}\right.$ Period $)$} \\
\hline & Country & $\mathbf{N}$ & TMCI & THC & Country & $\mathbf{N}$ & TMCI & THC \\
\hline 1 & USA & 15902 & $\begin{array}{r}\text { University of California } \\
\text { System (1447) }\end{array}$ & $\begin{array}{l}\text { China } \\
(1600)\end{array}$ & China & 32472 & $\begin{array}{r}\text { Chinese Academy of } \\
\text { Sciences (3312) }\end{array}$ & $\begin{array}{r}\text { USA } \\
(4609)\end{array}$ \\
\hline 2 & China & 10345 & $\begin{array}{r}\text { Chinese Academy of } \\
\text { Sciences (1264) }\end{array}$ & $\begin{array}{r}\text { USA } \\
(1600)\end{array}$ & USA & 18570 & $\begin{array}{r}\text { University of California } \\
\text { System (1419) }\end{array}$ & $\begin{array}{r}\text { China } \\
(4609)\end{array}$ \\
\hline 3 & Japan & 3865 & Osaka University (281) & $\begin{array}{r}\text { China } \\
(289)\end{array}$ & $\begin{array}{l}\text { South } \\
\text { Korea }\end{array}$ & 6277 & Korea University (505) & $\begin{array}{r}\text { USA } \\
(661)\end{array}$ \\
\hline 4 & $\begin{array}{l}\text { South } \\
\text { Korea }\end{array}$ & 3778 & Korea University (446) & $\begin{array}{r}\text { USA } \\
(583)\end{array}$ & India & 4976 & $\begin{array}{r}\text { Indian Institute of } \\
\text { Technology System IIT } \\
\text { System (942) } \\
\end{array}$ & $\begin{array}{r}\text { USA } \\
(424)\end{array}$ \\
\hline 5 & Taiwan & 3613 & $\begin{array}{r}\text { National Chiao Tung } \\
\text { University (468) } \\
\end{array}$ & $\begin{array}{l}\text { USA } \\
(314) \\
\end{array}$ & England & 4782 & $\begin{array}{r}\text { University of London } \\
(611) \\
\end{array}$ & $\begin{array}{r}\text { China } \\
(1123) \\
\end{array}$ \\
\hline 6 & Canada & 3203 & $\begin{array}{r}\text { University of Waterloo } \\
(398)\end{array}$ & $\begin{array}{r}\text { USA } \\
(582)\end{array}$ & Canada & 4239 & $\begin{array}{r}\text { University of Waterloo } \\
(421)\end{array}$ & $\begin{array}{r}\text { China } \\
(1129)\end{array}$ \\
\hline 7 & England & 2906 & $\begin{array}{r}\text { University of London } \\
(451) \\
\end{array}$ & $\begin{array}{l}\text { USA } \\
(326) \\
\end{array}$ & Japan & 4206 & Osaka University (266) & $\begin{array}{r}\text { China } \\
(607) \\
\end{array}$ \\
\hline 8 & Germany & 2659 & $\begin{array}{r}\text { Helmholtz Association } \\
(161)\end{array}$ & $\begin{array}{l}\text { USA } \\
(322)\end{array}$ & Taiwan & 3761 & $\begin{array}{r}\text { National Chiao Tung } \\
\text { University (381) }\end{array}$ & $\begin{array}{r}\text { China } \\
(517)\end{array}$ \\
\hline 9 & Spain & 2567 & $\begin{array}{r}\text { Polytechnic University of } \\
\text { Catalonia (323) }\end{array}$ & $\begin{array}{l}\text { USA } \\
(175)\end{array}$ & Australia & 3709 & $\begin{array}{r}\text { University of Technology } \\
\text { Sydney (443) }\end{array}$ & $\begin{array}{r}\text { China } \\
(1,414)\end{array}$ \\
\hline 10 & France & 2159 & $\begin{array}{r}\text { Centre National De La } \\
\text { Recherche Scientifique } \\
\text { CNRS (694) }\end{array}$ & $\begin{array}{l}\text { USA } \\
(287)\end{array}$ & Spain & 3565 & $\begin{array}{r}\text { Polytechnic University of } \\
\text { Catalonia (373) }\end{array}$ & $\begin{array}{l}\text { USA } \\
(264)\end{array}$ \\
\hline
\end{tabular}

\subsection{Analysis for Collaboration among Countries and among Authors}

Co-authorship analysis is a bibliometric technique that is used to reveal the collaborations between authors or other demographics (Gmür, 2003). This study investigated the relationships between the countries regarding the co-authorships regarding minimum of 50 articles (Figure 1). In general, the networks indicate that there are four main country clusters in collaborations which are independent of the continental decomposition. In particular, the articles were produced by 135 distinct countries in the first period and 161 distinct countries in the second period. Figure 1 presents only 52 countries in the first period and 76 countries in the second period which have at least 50 articles in the related subject area.

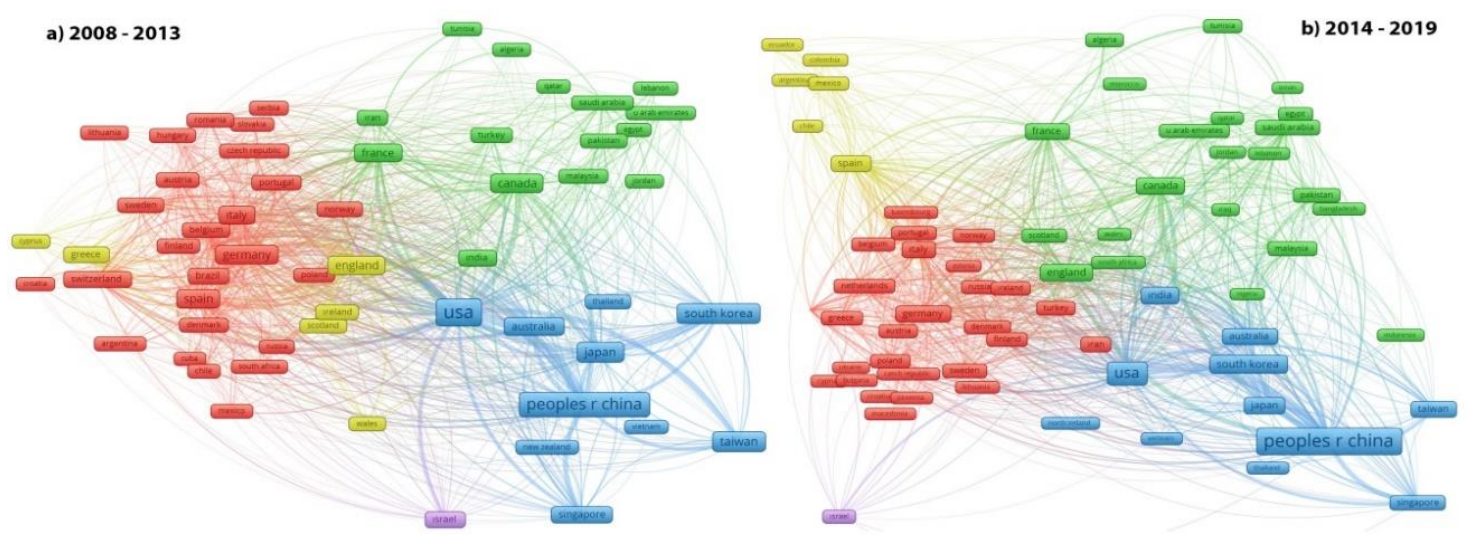

Figure 1. Co-authorship - Country Network (min 50 articles, left: 2008-2013; right: 2014-2019)

Further analysis of countries shows us that the US is still the main hub for this discipline. China is also becoming the main hub for collaboration. We also see that regional collaboration is still significant for most areas. For example England and surrounding countries Ireland, Scotland, Wales are creating a cluster. Also, Australia and East Asia countries are creating another cluster. This may be an indicator of different research streams and it should be analysed further. In terms of changes by the time, we can see that China is becoming more centralized and Israel's collaboration is shifting more toward European countries. Some countries are also showing shifts in their clusters. Many other significant analysis can be done. 


\subsection{Journal Analysis}

Table 4 shows the journal rankings for both periods. We see that IEEE journals are significantly leading mediums for this discipline. From the IS discipline perspective, it is sad to see that leading IS journals cannot be seen in this top 10 journal list. They are located well below in this table and it might be an indicator of IS importance in computer systems area. Most of the journal in this list are technical side of computer science and we can conclude that IS is not a significantly important partner for computer scientists as of yet. Computer Science field is still dominated by technical and engineering related issues rather than the human and managerial side. As IS community, we have very strong ties with the CS field and we should increase our weight in this discipline. In terms of contribution to journals we see a similar picture and for most of the journals China and US are main contributors and other leading countries in the list are taking their place in top three countries data. Of course, further analysis is needed for detailed and more meaningful interpretations. When both periods are compared, we can say that journal list is significantly different and more multidisciplinary journals are becoming more popular for the area researchers. Journals with the highest impact factors are Information Sciences $(4,378)$ and IEEE Access $(4,199)$.

Table 4. Top 10 Journals in the Related Area

\begin{tabular}{|c|c|c|c|c|c|c|c|c|}
\hline \multirow[t]{2}{*}{ \# } & \multicolumn{4}{|c|}{$2008-2013\left(1^{\text {st }}\right.$ Period $)$} & \multicolumn{4}{|c|}{ 2014-2019 ( $\left({ }^{\text {nd }}\right.$ Period $)$} \\
\hline & Sources & $\begin{array}{l}\text { Top Two } \\
\text { Countries }\end{array}$ & 5IF & $\mathbf{N}$ & Sources & $\begin{array}{l}\text { Top Two } \\
\text { Countries }\end{array}$ & 5IF & $\mathbf{N}$ \\
\hline 1 & $\begin{array}{l}\text { IEEE Transactions on } \\
\text { Information Theory }\end{array}$ & $\begin{array}{l}\text { USA (1604); } \\
\text { China (300) }\end{array}$ & 2.76 & 2985 & IEEE Access & $\begin{array}{l}\text { China (6680); } \\
\text { USA (1471) }\end{array}$ & 4.199 & 10961 \\
\hline 2 & Information Sciences & $\begin{array}{l}\text { China (787); } \\
\text { Taiwan (278) }\end{array}$ & 4.378 & 2374 & $\begin{array}{l}\text { Multimedia Tools And } \\
\text { Applications }\end{array}$ & $\begin{array}{l}\text { China (2026); } \\
\text { South Korea } \\
(602)\end{array}$ & 1.471 & 4782 \\
\hline 3 & $\begin{array}{l}\text { IEICE Transactions on } \\
\text { Fundamentals of } \\
\text { Electronics } \\
\text { Communications and } \\
\text { Computer Sciences }\end{array}$ & $\begin{array}{l}\text { Japan }(1492) ; \\
\text { South Korea } \\
(371)\end{array}$ & 0.303 & 2367 & Information Sciences & $\begin{array}{l}\text { China (1907); } \\
\text { USA (399) }\end{array}$ & 4.378 & 3825 \\
\hline 4 & $\begin{array}{l}\text { IEICE Transactions on } \\
\text { Information and } \\
\text { Systems }\end{array}$ & $\begin{array}{l}\text { Japan }(1098) ; \\
\text { South Korea } \\
(436)\end{array}$ & 0.398 & 2092 & $\begin{array}{l}\text { IEEE Transactions On } \\
\text { Information Theory }\end{array}$ & $\begin{array}{l}\text { USA (1158); } \\
\text { China (355) }\end{array}$ & 2.76 & 2454 \\
\hline 5 & $\begin{array}{l}\text { Journal of Chemical } \\
\text { Information and } \\
\text { Modelling }\end{array}$ & $\begin{array}{l}\text { USA (536); } \\
\text { Germany (235) }\end{array}$ & 4.112 & 1566 & $\begin{array}{l}\text { International Journal } \\
\text { of Distributed Sensor } \\
\text { Networks }\end{array}$ & $\begin{array}{l}\text { China (1217); } \\
\text { South Korea } \\
(460)\end{array}$ & 1.646 & 2127 \\
\hline 6 & Computer Networks & $\begin{array}{l}\text { USA (367); } \\
\text { China (157) }\end{array}$ & 2.589 & 1414 & $\begin{array}{l}\text { IEEE Latin America } \\
\text { Transactions }\end{array}$ & $\begin{array}{l}\text { Brazil (943); } \\
\text { Mexico (352) }\end{array}$ & 0.465 & 1960 \\
\hline 7 & $\begin{array}{l}\text { Computer } \\
\text { Communications }\end{array}$ & $\begin{array}{l}\text { USA (261); } \\
\text { China (222) }\end{array}$ & 2.681 & 1328 & $\begin{array}{l}\text { IEICE Transactions on } \\
\text { Information and } \\
\text { Systems }\end{array}$ & $\begin{array}{l}\text { Japan }(955) ; \\
\text { China }(590)\end{array}$ & 0.398 & 1894 \\
\hline 8 & $\begin{array}{l}\text { Information } \\
\text { Processing Letters }\end{array}$ & $\begin{array}{l}\text { China (277); } \\
\text { USA (198) }\end{array}$ & 0.723 & 1272 & $\begin{array}{l}\text { IEICE Transactions on } \\
\text { Fundamentals of } \\
\text { Electronics } \\
\text { Communications And } \\
\text { Computer Sciences } \\
\end{array}$ & $\begin{array}{l}\text { Japan (1087); } \\
\text { China (526) }\end{array}$ & 0.303 & 1854 \\
\hline 9 & $\begin{array}{l}\text { Journal of The } \\
\text { American Society for } \\
\text { Information Science } \\
\text { And Technology }\end{array}$ & $\begin{array}{l}\text { USA (435); } \\
\text { China (101) }\end{array}$ & 2.762 & 1090 & $\begin{array}{l}\text { KSII Transactions on } \\
\text { Internet and } \\
\text { Information Systems }\end{array}$ & $\begin{array}{l}\text { China }(905) ; \\
\text { South Korea } \\
(420)\end{array}$ & 0.543 & 1562 \\
\hline 10 & $\begin{array}{l}\text { International Journal } \\
\text { of Distributed Sensor } \\
\text { Networks }\end{array}$ & $\begin{array}{l}\text { China }(581) ; \\
\text { South Korea } \\
(173)\end{array}$ & 1.646 & 1047 & Computer Networks & $\begin{array}{l}\text { China (350); } \\
\text { USA (311) }\end{array}$ & 2.589 & 1457 \\
\hline
\end{tabular}

\subsection{Area Analysis}

Each article in WoS can be assigned to more than one research areas, the area with the highest frequency is naturally the selected area where others follow this area (Table 5). Country contributions are also given in the second column of Table 1 highlighting the similar findings to Table 3 and Table 4 . When both periods are examined, one can say that top-five research areas are exactly the same but rankings are different. The area information is also compatible with the top journals in the area as listed in Table 5. 
Table 5. Research Areas

\begin{tabular}{|c|c|c|c|c|c|c|c|c|}
\hline \multirow[t]{2}{*}{ \# } & \multicolumn{4}{|c|}{ 2008-2013 $\left(1^{\text {st }}\right.$ Period $)$} & \multicolumn{4}{|c|}{ 2014-2019 $\left(2^{\text {nd }}\right.$ Period $)$} \\
\hline & Research Area & $\begin{array}{l}\text { Top-Two } \\
\text { Countries }\end{array}$ & $\mathbf{N}$ & $\%$ & Research Area & $\begin{array}{l}\text { Top- Two } \\
\text { Countries }\end{array}$ & $\mathbf{N}$ & $\%$ \\
\hline 1 & $\begin{array}{l}\text { Computer Science } \\
\text { Information Systems }\end{array}$ & $\begin{array}{l}\text { USA (15803); } \\
\text { China (10320) }\end{array}$ & 57.347 & 100.00 & $\begin{array}{l}\text { Computer Science } \\
\text { Information Systems }\end{array}$ & $\begin{array}{l}\text { China(32455); } \\
\text { USA(18544) }\end{array}$ & 96219 & 100.00 \\
\hline 2 & $\begin{array}{l}\text { Engineering Electrical } \\
\text { Electronic }\end{array}$ & $\begin{array}{l}\text { USA (4143); } \\
\text { China (3279) }\end{array}$ & 16.262 & 28.35 & Telecommunications & $\begin{array}{l}\text { China (16352); } \\
\text { USA (6074) }\end{array}$ & 36103 & 37.52 \\
\hline 3 & Telecommunications & $\begin{array}{l}\text { USA (4384); } \\
\text { China (3023) }\end{array}$ & 16.049 & 27.98 & $\begin{array}{l}\text { Engineering } \\
\text { Electrical Electronic }\end{array}$ & $\begin{array}{l}\text { China(15044); } \\
\text { USA (5665) }\end{array}$ & 34671 & 36.03 \\
\hline 4 & $\begin{array}{l}\text { Computer Science } \\
\text { Software Engineering }\end{array}$ & $\begin{array}{l}\text { USA (2343); } \\
\text { China (2110) }\end{array}$ & 9.916 & 17.29 & $\begin{array}{l}\text { Computer Science } \\
\text { Software } \\
\text { Engineering }\end{array}$ & $\begin{array}{l}\text { China(6325); } \\
\text { USA (2500) }\end{array}$ & 15816 & 16.43 \\
\hline 5 & $\begin{array}{l}\text { Computer Science } \\
\text { Hardware Architecture }\end{array}$ & $\begin{array}{l}\text { USA (1823); } \\
\text { Japan (1661) }\end{array}$ & 7.396 & 12.89 & $\begin{array}{l}\text { Computer Science } \\
\text { Theory Methods }\end{array}$ & $\begin{array}{l}\text { China (3631); } \\
\text { USA }(1,380)\end{array}$ & 9722 & 10.10 \\
\hline
\end{tabular}

\subsection{Keywords, Clusters, and Topics}

Co-occurrence analyses were conducted for keyword clusters, density, and keyword trends over time (Figure 2, Figure 3 and Figure 4). Figure 2 focuses on the potential topics over keyword clusters so this figure visualizes the results of the text clustering analysis. The colours in Figure 2 highlight the clusters which indicate a particular topic or issue handled in the studies in the field. Figure 3 represents the closeness of the keywords again where the colours show the use of the words over time. More recent words approach to red whereas old ones are getting blue to the earlier years. The densities of these keywords were emphasized in Figure 4 again via a heat map to distinct the most frequent ones.

In this context, nine clusters were obtained for both periods. In the first period, cryptology, privacy and security, sensors and networks, artificial intelligence, data mining, web services, enterprise systems, data mining, text mining whereas in the second period green computing, energy efficacy, internet of things, big data, artificial intelligence, sensors, security, machine learning, feature selection, cloud computing and related issues are the leading topics. It can also be seen from Figure 3 that the density of these topics varies from year to year even for the same topic.

When we look at the recurrence of keywords for two periods we see that between 2008-2013 the mostly worked areas are algorithms, wireless sensor networks, energy efficiency, information retrieval, authentication, performance measurement, and routing. For 2013-2019 most recurring words are privacy, IOT, authentication, security, wireless sensor networks, cloud computing, machine learning, energy efficiency, social media, ontology, algorithms, and clustering. These keywords are showing us that by the time research topics are shifting as well and more current issues such as privacy, security, IOT, big data, etc. are being studied widely by the researchers in this area. It also indicates that IS researchers might have an opportunity to collaborate or become more significant in this discipline since these are also most widely studied topics in IS.
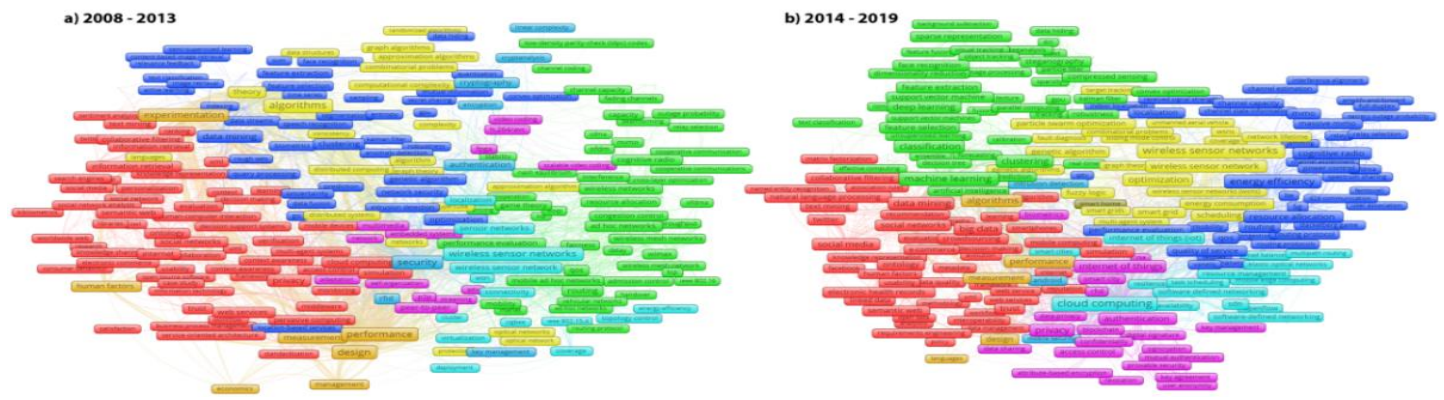

Figure 2. Co-occurrence-Author Keywords Network (min 40 keyword occurrences) 

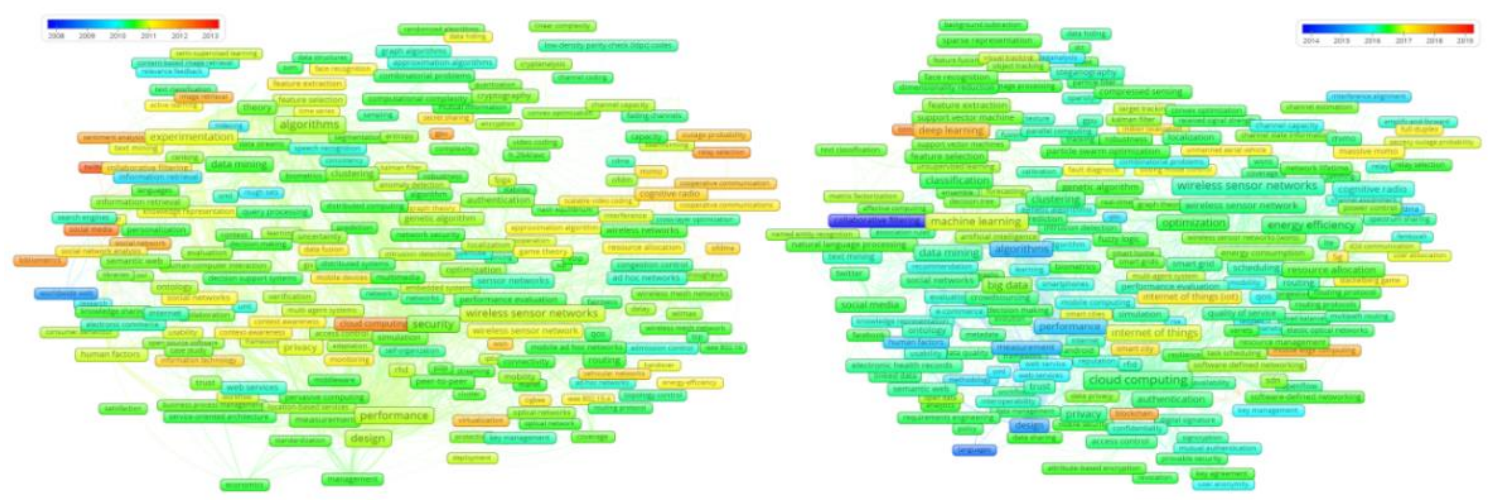

Figure 3. Co-occurrence-Author Keywords by Years (min 40 keyword occurrences)

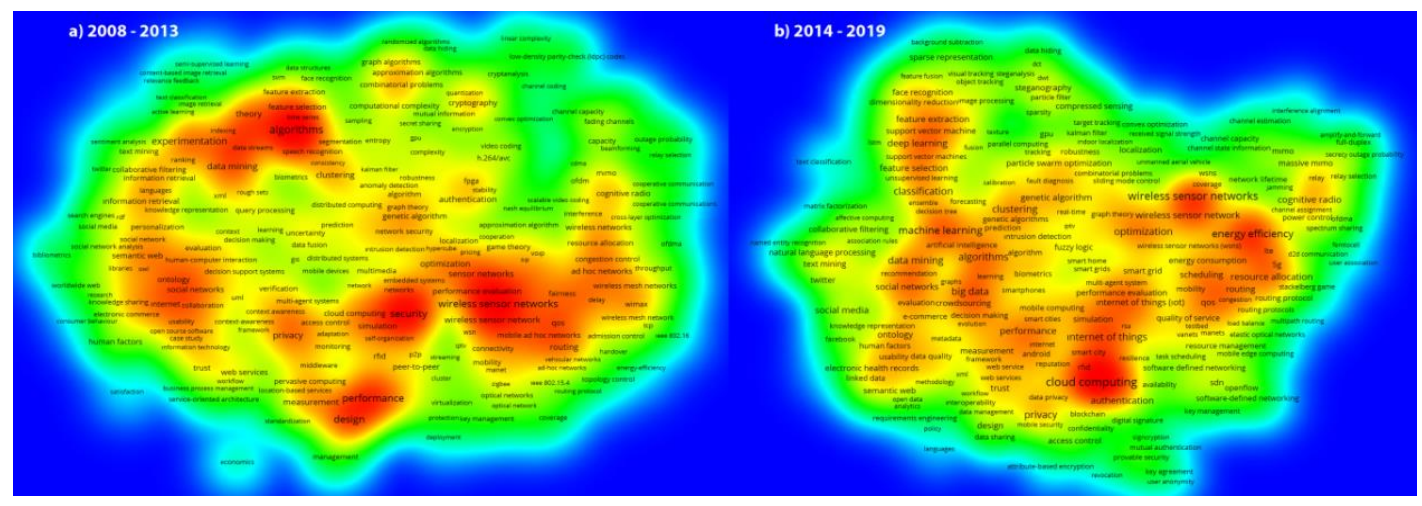

Figure 4. Co-occurrence-Author Keywords by Density (min 40 keyword occurrences)

\section{CONCLUSION}

This study revealed the particular characteristics of the literature regarding "Computer Science and Information Systems" over the articles categorized under the same title in WoS Core Collection. In this context, 57347+96219 articles were investigated through the related methods and techniques of scientometrics with respect to particular attributes such as countries, institutions, collaborations among the countries, journals, and topics. For each type of finding, several summary statistics, text and network analytics were used.

IS discipline and researchers need to understand the relationships and interactions, as well as understanding current trends in both disciplines for better collaboration CS and IS, should be completing each other with this mutual intersections and understanding. Thus, the findings may shed light on the future studies of the researchers in this field. For example, with co-authorship networks, the scientometrics studies provide author clusters which can help researchers to see idea and research groups from many countries and institutions in the corresponding research area. Keywords and topics over the keywords may indicate the current trends and the gaps in the area. We can see that the main topics have a lot of similarities, However, CS focuses on technical sides and IS should be focusing on human and managerial sides. Top journal list can be used while deciding about paper submissions regarding the country dimension, our significant finding is that China is becoming very dominant in this area by passing long term leader US. American and European universities that had high ranked in the first period have now been leaving their positions to Brazil, Spain, Taiwan, and Indian universities. Besides, there are particular country clusters showing the co-authorships. The researchers can use these findings to plan research visits or conference participations. Much more findings were obtained from the analyses, but could not be presented because of the manuscript limitations but will be included during our presentation. 


\section{REFERENCES}

Abbasi, A., Sarker, S., \& Chiang, R. 2016. Big Data Research in Information Systems: Toward an Inclusive Research Agenda. Journal of the Association for Information Systems, Vol.17, No.2, pp. I-XXXII.

Al, U. 2008. Evaluation of scientific publications: H-index and performance of Turkey. Bilgi Dünyası, 9(2), 263-285.

Alma, B., Koc, T., \& Coşkun, E. 2017. Analysis of research characteristics of MIS discipline in Turkey. Americas Conference on Information Systems: A Tradition of Innovation, AMCIS 2017, 2017-Augus, pp.1-10.

Banker, R. D., \& Kauffman, R. J. 2004. 50th Anniversary Article: The Evolution of Research on Information Systems: A Fiftieth-Year Survey of the Literature in Management Science. Management Science, Vol.50, No.3, pp. 281-298. https://doi.org/10.1287/mnsc.1040.0206

Cheon, M. J., Groven, V., \& Sabherwal, R. 1993. The evolution of empirical research in IS. A study in IS maturity. Information and Management, Vol.24, No.3, pp.107-119. https://doi.org/10.1016/0378-7206(93)90060-7

Choi, J., Yi, S., \& Lee, K. C. 2011. Analysis of keyword networks in MIS research and implications for predicting knowledge evolution. Information and Management, Vol.48, No.8, pp. 371-381. https://doi.org/10.1016/j.im.2011.09.004

Dickson, G. W. 1981. Management Information Systems: Evolution and Status. Advances in Computers, Vol. 20. https://doi.org/10.1016/S0065-2458(08)60494-5

Freitas, H., Luciano, M. E., \& Testa, G. M. 2004. Research topics in Management Information Systems : a comparative study. Colloque de l'AIM Systèmes d'information: Perspectives Critiques, Vol.9.

Garfield, E. 2009. From the science of science to Scientometrics visualizing the history of science with HistCite software. Journal of Informetrics, 3(3), 173-179.

Glänzel, W., \& Schoepflin, U. 1994. Little scientometrics, big scientometrics... and beyond?. Scientometrics, 30(2-3), 375-384.

Gmür, M. 2003. Co-citation analysis and the search for invisible colleges: A methodological evaluation. Scientometrics, Vol.57, No.1, pp.27-57.

Hood, W., \& Wilson, C. 2001. The literature of bibliometrics, scientometrics, and informetrics. Scientometrics, 52(2), 291-314.

Palvia, P., Mao, E., Salam, A. F., \& Soliman, K. S. 2003. Management Information Systems Research: What's There in a Methodology? Communications of the Association for Information Systems, Vol.11, No.March, pp. 289-209. Retrieved from http://aisel.aisnet.org/cais/vol11/iss1/16/

Paré, G., Trudel, M. C., Jaana, M., \& Kitsiou, S. 2014. Synthesizing information systems knowledge: A typology of literature reviews. Information and Management.

Sengupta, I. N. 1992. Bibliometrics, informetrics, scientometrics and librametrics: An overview. Libri, Vol.42, No.2, pp.75-98.

Serenko, A., Cocosila, M., \& Turel, O. 2008. The state and evolution of information systems research in Canada: A scientometric analysis. Canadian Journal of Administrative Sciences, Vol.25, No.4, pp. 279-294. https://doi.org/10.1002/cjas.73

Shao, P., Wu, L., \& Zhou, B. 2014. A Comparative Study on MIS Research at Mainland China and Abroad (2002-2010). In Association for Information Systems AIS Electronic Library (AISeL) WHICEB 2014 Proceedings Wuhan (Vol. Summer 6-1).

Siluo, Y., \& Qingli, Y. 2017. Are Scientometrics, Informetrics, and Bibliometrics different?. In Conference: The 16th International Conference on Scientometrics \& Informetrics (ISSI2017).

van Eck, N., \& Waltman, L. 2009. Software survey: VOSviewer, a computer program for bibliometric mapping. Scientometrics, 84(2), 523-538.doi:10.1007/s11192-0090146.

Vessey, I., Ramesh, V., \& Glass, R. L. 2002. Research in information systems: An empirical study of diversity in the discipline and its journals. Journal of Management Information Systems, Vol.19, No.2, pp. 129-174. https://doi.org/10.1080/07421222.2002.11045721 